\title{
Design Sprint versus Design Thinking: A comparative analysis
}

Lucas Baraças Figueiredo Correio ${ }^{1}$, Depto. de Engenharia de Produção da Escola Politécnica da Universidade de São Paulo André Leme Fleury², Depto. de Engenharia de Produção da Escola Politécnica da Universidade de São Paulo

\section{ABSTRACT}

Context: Design Sprint (DS) is a new design methodology for designing new products that resembles Design Thinking (DT) in designing solutions that diverge and focus on the problem and solution fields, to be then tested in prototypes. Yet it differs from DT by incorporating Lean Startup concepts such as agility and elimination of costly or low-value activities. Although it gained increased interest in the organizational world, it is still unexplored in the literature, without an analysis of best practices, and how this process may be more appropriate than traditional DT processes. Objective: In spite of the improvements proposed by the design community to the original process, this study aims to perform a comparative analysis of the DS process, as prescribed in the book that originated the methodology, against traditional DT processes, considering its phases and techniques, and what the advantages and disadvantages of each methodology are. Method: The research used the methodological approach of multiple case study by evaluating three DS processes in a company that executes processes with both methodologies. In addition to observing the processes and documenting the decisions made, six interviews were conducted with company partners and experts from the area, who participated in the processes. Results: The article describes the execution of DS processes in detail and then summarizes the advantages of these processes against DT processes, such as: low experimentation barrier, alignment with high management for continuing the work, orientation to incremental innovations. Nevertheless, the coexistence of the two methodologies is proposed, such that DS can be more efficient when used as an initial stage of requirements of new products, while DT proves to be more useful as a methodology for generating new ideas. Conclusion: The research on theoretical and practical contributions by investigating a topic not yet explored in the literature, positioning positive and negative aspects of DS in relation to other more established design methodology (DT), and suggesting how these methodologies can be applied more efficiently to creating new products and services.

Keywords: Sprint Design, Design Thinking, Lean Startup, Product Development, Case Study.
Editor Responsável: Prof. Dr. Hermes Moretti Ribeiro da Silva

1. Av. Prof. Luciano Gualberto, 1380 - Butantã, São Paulo - SP, 05508-010, baracasfig@ gmail.com; 2. andreleme.fleury@ gmail.com

CORREIO, L.B.F.; FLEURY, A.L. Design Sprint versus Design Thinking: A comparative analysis. GEPROS. Gestão da Produção, Operações e Sistemas, v. 14, n. 5, p. 23 - 47, 2019. 


\section{INTRODUCTION}

In a globalized scenario, where competition for markets and consumers is increasing, there is a condition whereby the creation of products and services that consumers need or want is no longer a competitive differential and becomes a necessity (BECKMAN; BARRY, 2007; DA SILVA et al., 2018). This area of innovation and new product development is so dynamic that even the renowned author of the Stage-Gate model needed to update his theory from the 1980s on how to create successful products multiple times (COOPER, 1994, 2008, 2011, 2014).

The risks involved along with a number of variables, present in the creation of new products, make this process a wicked problem (RITTEL; WEBBER, 1973), that is, it fits problems to which there is no correct solution, if not just better or worse solutions.

According to Buchanan (1992), an approach that is relevant to solving these types of problems is Design Thinking (DT), because the design is capable of conceiving and planning what does not exist, as required for wicked problems.

This DT approach, which essentially means using the principles, methods and tools of design for solving problems (BROWN, 2009) has gained increase interest and became a trend, for achieving innovation, and in spite of the exaggeration, has even created a panacea in the organizational world as a possible solution to all problems (BICEN, JOHNSON, 2015).

Despite its low intersection with DT in the literature, another very appropriate approach for developing new products is Lean Startup (LS). This approach dates back to the 1980s with lean production principles, advocating concepts of cost reduction and lean production, and has been widely used not only by startups but also by a number of companies working in high uncertainty contexts (BLANK, 2013).

According to Mueller (2012), this LS approach, as DT, is also used to increase the chances of success of the product development process by using fast interaction cycles and a user centric approach.

The application of both these concepts to the development of new products has gained strength mainly with Design Sprint (DS) as one of the first methodologies that unifies the concepts of LS and DT and the possibility of being used by any person or organization in an autonomous way without prior knowledge (KNAPP et al., 2016). According to Knapp et al. 
(2016), DS allows learning more about the end consumer and reducing uncertainties during a product design quickly and inexpensively optimize the company's resources and to better align the product with customer expectations to increase the chances of success. These factors made practitioners of the area mark DS as one of the most widely used design methodologies in the Brazilian market (TEIXEIRA, 2017). Despite the popularity in the organizational field, DS is still in a very early stage in the literature, with recent publications on workshops and isolated case studies (SHIN, THOMAS, 2015, THOMAS, SHIN, 2016, BROERS, REUVER, 2016; 2017). This work aims to analyze DS with an unprecedented perspective, its basic concepts of DT and LS and focusing on the changes that this new process brings to traditional processes of DT for developing new products.

This paper aims to answer the following questions: (1) what are the conceptual differences between this Design Sprint methodology and the Design Thinking one, (2) what benefits and limitations does Design Sprint present in comparison to the applications of design techniques already seen in Design Thinking processes within a product development context and to justify (3) why has Design Sprint achieved so much evidence in the market?

Motivated by these questions and from an academic perspective, this work intends (a) to systematically analyze the DS process based on the bibliographic references of DT and LS and from a practical viewpoint, (b) to comparatively evaluate DS through three new product development processes compared to traditional DT processes in a technology company that uses both design methodologies.

Thus, this research aims to bring contributions by exploring this still incipient area in the academic environment (MUELLER, 2012) and unprecedented in the correlation with the theme of product development; and bring a better understanding to organizations that always seek new references for developing products that consumers need or want in increasingly effective ways.

The remainder of the paper is structured as follows. Section 2 presents a literature review. Section 3 presents the research methodology and the context involved. Sections 4 and 5 describe the application case, results and discussion. The paper ends in section 6 with a conclusion and directions for future investigations. 


\section{THEORETICAL BACKGROUND}

\subsection{Product development as a wicked problem}

According to Rittel and Webber (1973), there are two categories of problems, whose classification is related to their degree of indeterminacy. On the one hand, the determined problems refer to those that can start from an analytical approach in their definition and a linear sequence of activities until a correct solution is found. These are the kind of problems that scientists solve. An example of a problem in this category would be the replacement of a human assembly line with automated machines.

Differently, there are problems that are not possible to define analytically, and which allow for different plausible formulations according to the point of view adopted (SIMON, 1973). This indeterminacy can only be partially overcome by opting for some aspects to the detriment of others; this can only generate better or worse solutions, but never correct or final ones. Rittel called the latter class wicked problems in the 1960s (BUCHANAN, 1992).

These issues with problems of centralization, non-linearity and constant presence of uncertainties and ambiguities require a designer's ability to solve problems. Instead of using linear and analytical processes, the designer uses an experimental approach to test multiple solutions (RITTEL, 1972).

According to the Rittel and Webber's (1973) formulation, product development falls into this category of problems, because this is a social problem that depends on several points of view, it is usually difficult to formulate (too complex to be defined in a closed system ), and information can be confusing, and especially when customers and decision makers have conflicting values.

Owen (2007) believes that using DT is highly recommended for tackling this kind of problem because, in contrast to traditional management approaches, it continually avoids making decisions for as long as possible, with the strategy of maximizing learning and thus reducing uncertainties (LIEDTKA, 2015).

\subsection{Design Thinking (DT)}

The term Design Thinking (DT), which first appeared in Peter Rowe's (1987) book, initially referred to using design for the architectural context. Over time, DT has also begun to 
be used in the field of business as the use of design practices for problem solving in any area of human experience (BUCHANAN, 1992).

Although there is no consensus on an exact definition of the term, one of the most accepted proposals is currently IDEO's CEO Brown (2008): "a methodology that concatenates the full spectrum of activities in innovation with the character of human-centered design", that is, to identify solutions based on users' wishes and needs. Complementarily, Thomaz Lockwood (2009), of the Design Management Institute, defines DT as "the human-centered innovation process that emphasizes observation, collaboration, rapid learning, brainstorming, rapid prototyping of concepts and business analysis under different perspectives".

According to Dorst (2011), the DT process differs from traditional problem-solving approaches because it is not based on the assumptions that the researcher always has two factors to solve the equation:

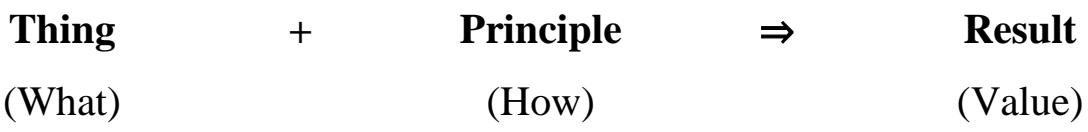

When using DT, the researcher stops using deductive or inductive approaches, starting with abductive thinking, not finding the correct answer, but the best possible answer. It is this difference of paradigm that makes the process of DT ideal for solving wicked problems (BROWN, 2008; WYLANT, 2008).

DT presents five main characteristics: 1) a human-centered approach 2) experimentation of artifacts 3) collaboration in interdisciplinary teams 4) holistic view of complex problems 5) a process with moments of divergence and convergence in six stages consolidated by Plattner et al. (2009). These involve user, market and business understanding, observation of the context of use, definition of the most relevant insights and problems to be attacked, "ideation" for generating ideas/solutions, "prototyping" of the solution and "validation" of the prototype with end-users (GEISSDOERFER et al., 2016). An abstraction of the DT process can be seen in Figure 1. 
Figure 1 - Process of creating new products and services through Design Thinking

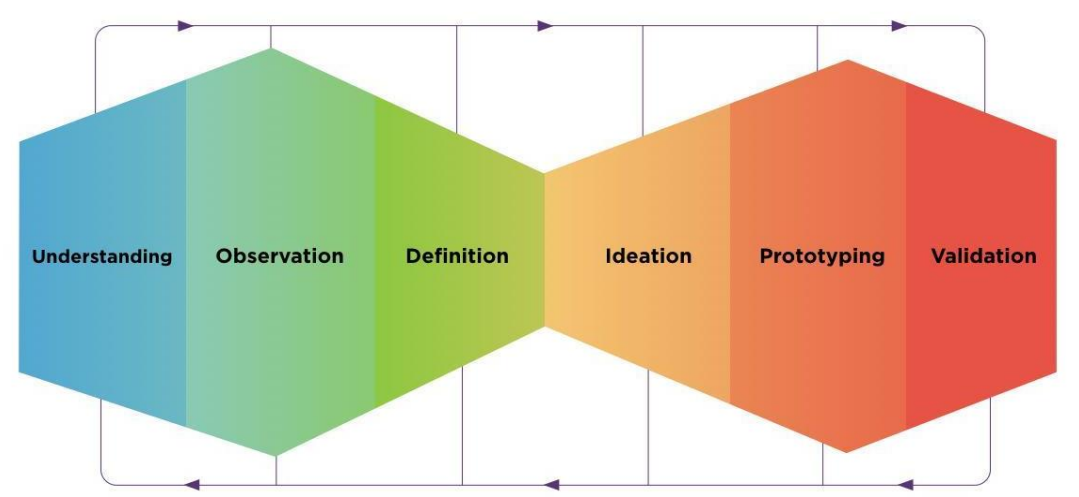

Source: Adapted from Geissdoerfer et al., 2016.

\subsection{Lean Startup (LS)}

The fundamental principle of Lean Startup (LS), is based on production optimization and is not new, having originated in Toyota - Japan (WOMACK, 2003). The main idea of the lean process is to reduce expenses, be they material or personal. The which started in the automotive industry, has also become popular in other areas, such as IT, product development, business creation, among others (HARMS, 2015).

The most recent LS concept has its main definition in the book by the same name "The Lean Startup" (RIES, 2011), in which startup is "a human institution designed to create new products and services in conditions of extreme uncertainty." Unlike the popular concept, startups are not necessarily small businesses, but they can be a specific department of a large company working with something uncertain.

The unfolding of lean production principles, for the current concept of LS was introduced in the context of software startups and claims that the most efficient innovation is the one for which there is an actual demand by the users, as seen in DT. Or put in other words: the biggest waste is creating a product or service that nobody needs (MUELLER, 2012). This concept is further detailed in the guidelines below:

Eliminate uncertainties: the methodology allows entrepreneurs to create order, not chaos, test their views continuously. Thus, the term lean is also related to understanding the business process related to product development capable of capturing the value perceived by the customer, with economy, quality and simplicity of the product created; 
Working in a more agile way, no longer harsh: the methodology is based on the premise that every startup is a great experiment trying to answer the questions: "Is this product to be built?", " Can we build a sustainable business around this set of products and services?". Thus, LS recommends anticipating learning throughout the construction of a product;

Developing a Minimum Viable Product (MVP): A key component of the methodology is the build-measure-learn cycle. The goal of a MVP is to shorten the time taken to launch a product, to test the business model, and to learn how to continually meet the needs of the end-users of a solution.

\subsection{Design Sprint (DS)}

The consulting firm IDEO was one of the main forces for the rapid expansion of the term DT and for applying design techniques to the corporate world, not only for the good results presented as Apple's first mouse, among other works with Coca-Cola, IKEA, Ford, but mainly for the guerrilla tactics of sharing guidelines with design techniques, also known as "toolkits", which help any person or organization to execute the DT process in an autonomous way. Examples are: Human-centered design toolkit (2009), Design thinking for educators (2011) and The field guide to human centered design (2015).

In addition to IDEO, there are other references that have also created their own guides with design techniques, such as the Stanford Design School (D. SCHOOL, 2010) with Bootcamp Bootleg (2011), Lahti Finland's innovation school with the Playbook for Strategic Foresight and Innovation (CARLETON et al., 2013), among others.

Among the many options that have emerged in the market, the methodology that is most evident, conceived by Google Ventures, is the Design Sprint (DS) process (KNAPP et al., 2016). DS differs from other guides by incorporating the concepts of LS, DT, ease of application and the ability to achieve good results in a very short time. Unlike the previous materials, which were a compilation of design techniques disconnected from each other, DS proposes a closed model with specific and sequential methods, and a discussion about the principles related to the adaptation of the model to different contexts. A rich discussion of this integration can be seen in a relaxed conversation conducted by Google among the top exponents of each theme, Tim Brown, Eric Ries, and Jake Knapp in Hangouts for Entrepreneurs, 2014. 
The DS model in Figure 2 shows some differences in the model of Geissdoerfer et al. (2016), with a decision-making stage regarding the best idea generated in the divergence stage (ideation) to focus only on the main ideas of the solution to be validated, an estimated time to perform the process and a unidirectional flow. This means to keep the process always objective, without diverging from the focus of the sprint (influence of lean principles).

Figure 2 - Process for creating new products through Design Sprint

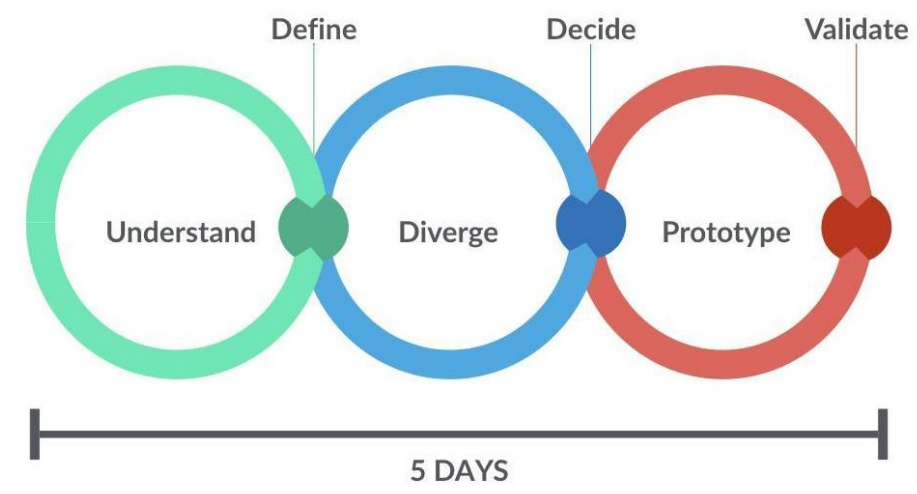

Source: Google Ventures, 2016.

\subsubsection{Methods and Design Sprint workflow}

Despite several evolutions in an active digital community, in its original version, the DS process (KNAPP et al., 2016) consists of the following sequential steps:

\subsubsection{Pre-Sprint}

Step One: Choosing the challenge and the team. Before starting a DS, it is necessary to have a multidisciplinary team (BROWN, 2008) with a facilitator (team leader) and a decisionmaker to ensure that decisions are aligned with the company's strategy, and a major challenge to be solved (wicked problem) complex enough to motivate participants (DESIGN THINKING FOR EDUCATORS, 2011).

\subsubsection{Understanding and definition}

Step Two: Definition of the long-term objective. Seeking an optimistic view of the project: "What results will we have if the challenge selected is well resolved?". 
Step Three: Alert Hypotheses: "How can we fail?" Understanding the potential risks that should be circumvented while building the solution.

Step Four: User Journey. This step consists in mapping the end user experience when using a product / service to be created and deciding which moment of the journey has more problems and opportunities to explore in the rest of the sprint.

Step Five: Talk to Experts. The experts in the subject should deliver a presentation to the sprint participants with their views on the issues and opportunities to be addressed and clarify business or technical doubts of the process participants.

Step Six: Hypotheses of Opportunity: "How might we ...?" Based on the conversation with the experts, the participants list the most relevant problems and opportunities to be solved in question format (D. SCHOOL, 2010), (DESIGN THINKING FOR EDUCATORS, 2011) (THE FIELD GUIDE TO HUMAN CENTERED DESIGN, 2015).

Step Seven: Redefining the Challenge. Post-it voting as a method of group decisionmaking, in which process participants choose the main problem or opportunity to be addressed in the rest of the sprint (D. SCHOOL, 2010).

\subsubsection{Divergence and Decision}

Step Eight: Benchmarks. Study of the references in the theme to find ideas of how other market solutions solved similar challenges (VIANNA et al., 2011).

Step Nine: Silent Brainstorm. With the inputs from the previous step, the participants individually create ideas to solve the proposed challenge (CARLETON et al., 2013).

Step Ten: Decision of the best solution. New post-it voting, with the choice of the best ideas to compose a solution (D. SCHOOL, 2010).

\subsubsection{Prototyping and validation}

Step Eleven: Storyboard and hypotheses. Creation of a product journey map (low fidelity prototype) with the concept proposed by the solution chosen in the previous step, and the hypotheses to be validated with the prototype (DESIGN THINKING FOR EDUCATORS, 2011). 
Step Twelve: Prototyping the solution. Based on the storyboard, creation of the high fidelity prototype to be tested by the users of the solution, to evaluate the concept of the new product (THE FIELD GUIDE TO HUMAN CENTERED DESIGN, 2015) (D. SCHOOL, 2010).

Step Thirteen: Validation. Qualitative test of the prototype with end users of the solution, and validation of hypotheses created in the sprint (THE FIELD GUIDE TO HUMAN CENTERED DESIGN, 2015).

\section{METHOD}

The main objective of this research is to systematically analyze the DS process, based on the theoretical references of DT and LS, and to evaluate the practical differences of this type of process with others based only on DT and through the previous investigations to justify the importance of this method for companies that aim to increase assertiveness in the development of new products. These objectives are based on the following research questions: (1) what are the conceptual differences between Design Sprint and Design Thinking, (2) what benefits and limitations does Design Sprint present faced with the applications of design techniques already foreseen in processes with Design Thinking in a product development context, and (3) why is it so prominent in the market?

Considering the exploratory context of the topic of research in the literature, the selected methodological approach was a multiple case study, since it is a research strategy that allows an understanding of the current dynamics and questions the facts with different methods (EISENHARDT, 1989). The methodological procedure adopts the approaches of Voss et al. (2002), and contemplates the evaluation, through participant observation (BRESSAN, 2000) of three DS processes (in the workshop model). Each consists of a multidisciplinary group of about 10 people composed of engineers, designers, project managers, software developers, among others, carried out within the AppsMobile company. After the workshops, six semi-structured interviews were conducted with experts (user experience consultants' and designers who supervised the process) and with participants. 
AppsMobile has been working with DT, both in internal processes and consulting with these paradigms since 2010. Since 2015, it has used the manuals and content of Google Ventures to perform DS.

The DS methodology was chosen to solve a wicked problem, which, in this case, was reformulating a digital product that over time won many competitors and needed to be revised to continue to be competitive in the market. Each of the DS processes analyzed the product from different perspectives: platform disclosure model (how will other companies discover this tool?), Business model (how will other companies acquire the product?), Usability of the tool (how can we lessen the demand for platform support?).

The workshops were held for two consecutive weekends. Participants in the three processes were invited to read Knapp's book (2016); the process facilitators and decision makers already had experience in the process.

For the company, the main purpose of this work was to help the roadmap improvement of a product here named AM1, and other secondary objectives, such as increasing integration among employees, training the professional body to carry out DS for internal and external processes in the company.

For data collection, the processes were partially filmed and real-time notes were taken; the interviews were recorded and then transcribed to facilitate later analysis. For analyzing the processes and the interviews, the paradigms of exploratory and interpretative research were adopted. Exploratory research reduces the literature-oriented trend and identifies new problems and interpretive research points out problems from the users' point of view. I am therefore able to understand any bias in the observation of events (CROOM, 2009).

\section{RESULTS}

\subsection{Pre-Sprint and Process Introduction}

The only activity performed out of the days dedicated to the process was a consultation with the company's partners on what the focus of DS processes should be. The process was started by a self-presentation activity followed by a presentation of the DS focus: "Show the actual value of AM1 for the client." The decision-makers of each team were also presented to 
each of the multidisciplinary groups, to ensure the adherence of the solution to the company's positioning strategy.

\subsection{Understanding and Defining}

After defining the scope, a brainstorm was carried out in the second step with the following scope: "If we could decide what we would like to achieve with our product, in two years what would the result be?". After many ideas, most of them converging, it was defined by the following: "AM1 becoming a one-to-one communication tool reference."

During product development processes, lean processes face rapid failure as a learning advantage and, therefore, entrepreneurs must be constantly prepared to fail (BLANK, 2013). To understand that these disagreements are part of the process, and to avoid making the wrong decisions during the sprint, a compilation of questions was made regarding what should be discussed and could potentially lead to product failure. That said, for the third step, to avoid confusion and bias when generating ideas, first each person wrote their own questions down on post-its, and then the questions were exposed to the groups.

The mapping of the user's journey, present in most of the practical guides of DT (IDEO, 2011); (D. SCHOOL, 2010); (KNAPP et al., 2016), is the first technique of this process oriented to thinking from the user's point of view. In this fourth step, it became evident that it is difficult to determine exactly the most important points of contact of a consumer with a B2B software, since the final consumer could be multiple users with different profiles. Yet, with some effort and understanding by the participants, a user's journey was created that interacts with the different areas of the company: commercial team, development team, support team, and even the tool itself.

For the interview stage with experts, strategic presentations were made to supply the participants of the process with different views of the product: commercial vision, technical vision and operational vision of the product use. From these, participants who often knew only one vision of the product, were able to have a richer vision of the whole, thus preparing for the next steps.

In the sixth step, the participants mapped the problems and opportunities of the AM1 product through questions employing the "How might we" technique (BERGER, 2012). These 
potential questions mapped are easier to answer with drawings, prototypes, and tests (KNAPP, 2016). At the end of this stage, more than 20 challenge-questions were raised and the participants seemed very eager to start working on the challenges mapped.

In tricky problems, a multitude of variables is normal. Unlike classical problem-solving processes, it is important to eliminate variables of lesser relevance (BLOMBERG; BURRELL, 2008).

Therefore, the objective of the next stage was to carry out a vote in regarding the challenges. If these were solved, greater benefits to the product would follow. The voting used the post-it voting technique. In it, participants have a limited number of votes to pick the most relevant questions, and they do so in silence to avoid biases, natural to processes in which participants end up accepting the choice of the most expressive stakeholder.

In the seventh stage, choosing the three most relevant challenges (one for each multidisciplinary team), one of the decision-makers chose to use their decision-making vote to change the course of the process. At first, the participants were surprised by the decision, but when listening to the decision maker's reasons, they understood the decision and accepted the new challenge.

For these first steps, the participants of the different teams formed a single group, to take advantage of the understanding that the ecosystem of the product was similar for all the fronts and to guarantee the alignment of the solutions. For subsequent steps, participants were separated into three teams, each with a specific challenge.

\subsection{Divergence and Decision}

From this stage on, the rest of the reported process refers to the TEC2 team, with the challenge "How can we reduce the need for customer support?".

Before beginning any type of research, to further understand what the platform current support demands were, the technical product leader simulated the platform and highlighted the points for which customers most requested help.

In the new step, participants took the time to conduct a brief online survey for benchmarks. To increase the diffusion of ideas in the group, each participant had the 
opportunity to present the most relevant benchmarks that could be used as references in the ideation stage.

According to Knapp et al. (2016), the best ideas emerge from individuals rather than from groups. Normally, group discussions end up valuing ideas that are best "sold" and not necessarily the best concepts; the process of ideation carried out thus used two individual procedures. In the tenth step, participants created potential solutions to the problem individually in an illustrated history format. When visualizing the proposal of each of the participants, many stories were verified to have convergent ideas.

In the next stage, there were again polls with post-its to choose the best ideas to be prototyped.

\subsection{Prototyping and validation}

After defining the best ideas to solve the proposed challenge, the storyboard method was used. The storyboard is a draft of the prototype, whereby participants can perform various simulations and perceive any errors and points of confusion before starting to build the highfidelity prototype of the solution.

With the storyboard defined, the group constructed the prototype considering 4 subtasks: construction of the artistic components (buttons, tables, etc.) of the prototype; creation of the flow between the components of the prototype; definition of written content of the prototype; and script of interviews to conduct the prototype tests.

In the latter stage, each group had the opportunity to present to the whole company how the rest of the process was after the teams separated. Three presentations were thus delivered with very different approaches to each other, based on the direction each process took. Note that, considering the aspects of software product raised and the nature of the activities performed, the validation performed in these processes was in the stakeholder validation model, differently from the user validation model quoted in the book by Knapp et al. (2016).

The first team to present was TEC3. Their goal was to solve the challenge: "How can we show the customer that AM1 is more than what they know?" This group understood that there were several points in the process, from the commercial stage to the implementation of 
the product in the client company, to be reviewed. The results were documentations and proposals for changes in the product and in the company processes.

The second team to present was TEC1, whose challenge was: "How can we best promote our tool in the market?". This group had a great deal of rework during the process because, at one of the moments, the group's decision-maker understood that the team was heading towards an unwanted path and that the group should redo some stages of the process. Eventually, they could not start the storyboard on the second day and consequently did not present the prototype, but rather the idea / solution most voted and what the next steps would be to execute that idea.

The last presentation was from the TEC2 group, when the steps described above were reported, together with the already functional prototype and customer interviews script. One point that was put forward by the TEC2 team's decision-maker is that most people in this group had already read the book by Knapp et al. (2016) and some other references of DT. This greatly helped the process in this group, as also proposed by Brown (2008) that non-designer professionals with the necessary attributes and training can master this type of process.

At the end of the presentations, the atmosphere was very enthusiastic; participants and company's managers were eager to develop the ideas/solutions of the process. 
Figura 3 - Design Sprint Steps
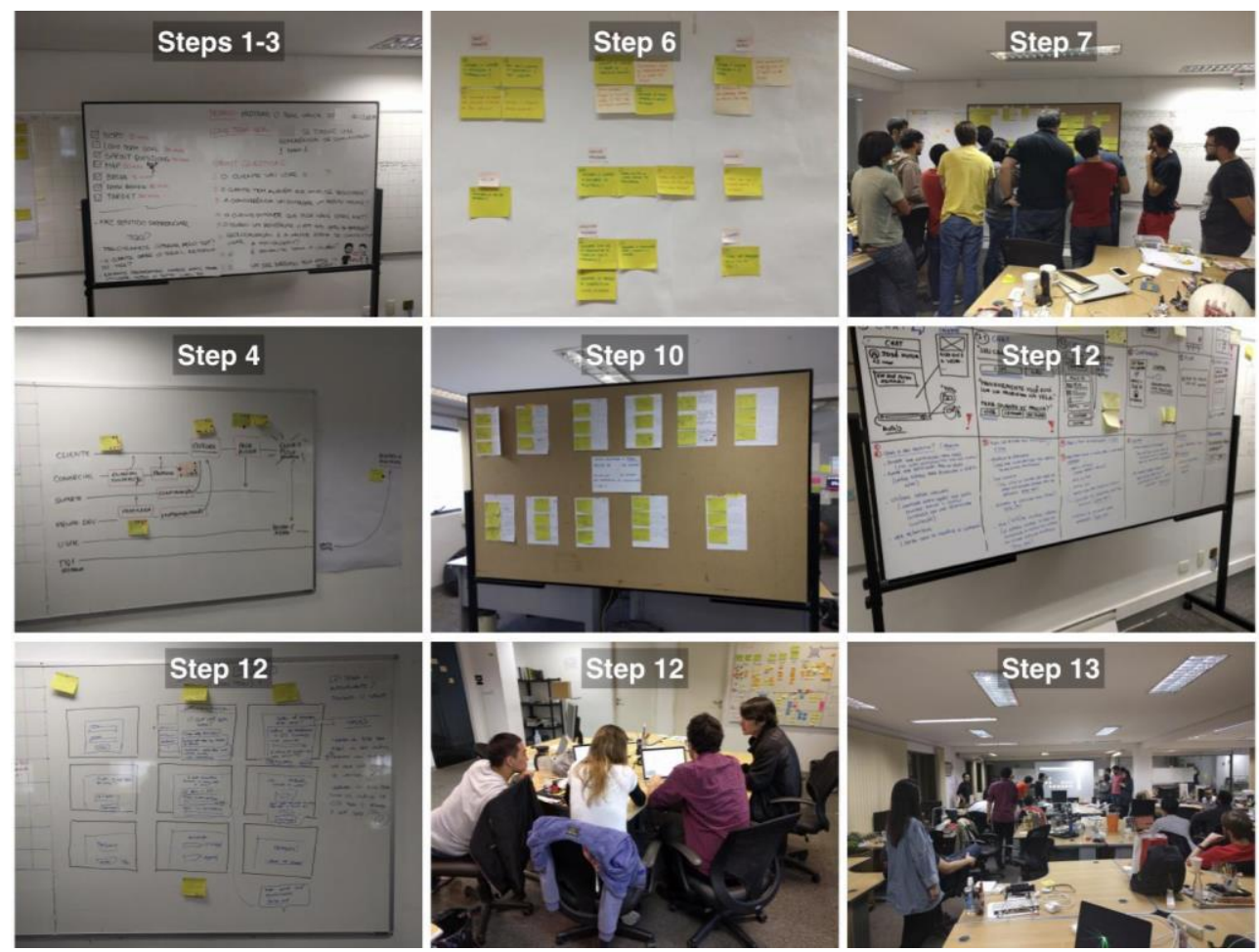

Source: Created by the authors, 2018.

\section{DISCUSSION}

\subsection{Differences between Design Sprint and Design Thinking processes}

The interviews were carried out with four partners of the company and two experts who followed the processes as observers, in order to identify the differences of this DS process with previous DT processes the company had conducted. In view of these, the main differences between the processes in each of the stages were summarized in Table 1.

Table 1 - Advantages and disadvantages of Design Sprint versus Design Thinking processes. 


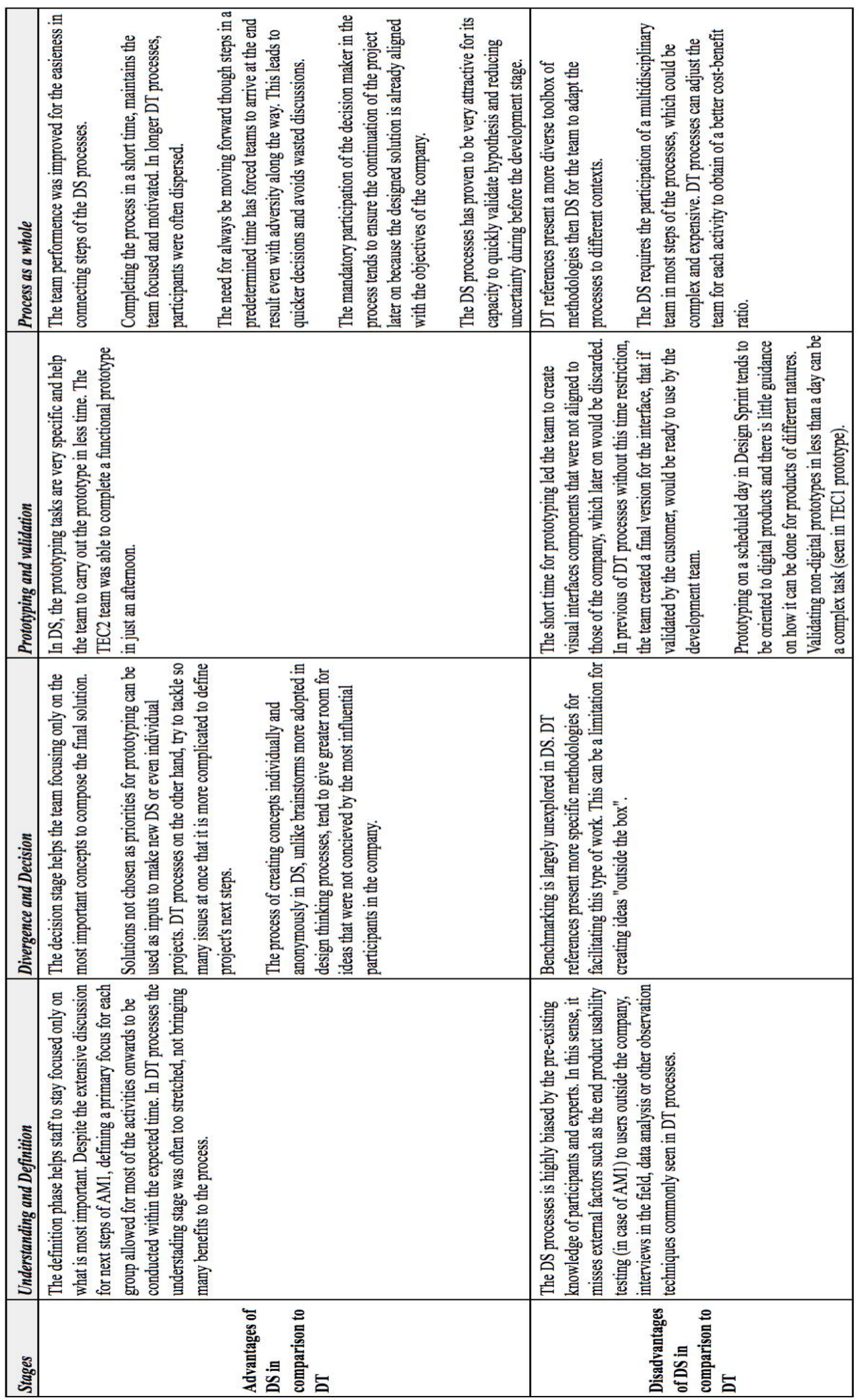

Source: Created by the authors, 2018 . 
As seen in Table 1, there are several reasons why the DS process has gained such evidence in Brazilian companies.

Low barrier of experimentation: Because it is a short process, it is possible to justify a low investment for the company that performs it. Also, for it is a well defined process, any employee/company can begin to internally carry out processes of this nature.

Alignment with top management "ensures" the continuation of work: The participation of a top management stakeholder guarantees the solution proposed will be aligned with the company's objectives. This allow the project to be designed directly at the development stage, without going through the project selection stage (CARVALHO; RABECHINI, 2011). Therefore, it is not only a great motivator for the sprint participants (who are producing something that will probably come off the paper), but it also eliminates unnecessary spending, wasting efforts into generating ideas that will be discarded.

Oriented to incremental innovations: Due to its leaning nature, discussions are always focused on what the priority is and on creating solutions that can be tested with any consumer, DS limits the potential of creating solutions that produce a radical innovation. Because of its continuous and incremental LS influences, DS tends to devise solutions that bring incremental, lower-risk innovations, which are easier to obtain and to be managed by startups.

These three arguments of low-cost implementation, a guarantee of alignment with the company's objectives and the orientation towards continuous and incremental innovations, suggest that, unlike the DT processes that are used to generate ideas (DOROW et al., 2016), DS can be best explored as a methodology to be undertaken as an initial part of large projects prior to their development, to address project uncertainties and to reduce product / project uncertainties as a whole, as adapted from the innovation process funnels in Figure 4 (KOEN et al., 2001). 
Figure 4 - Design Thinking and Design Sprint processes can be used at different stages of new product development.

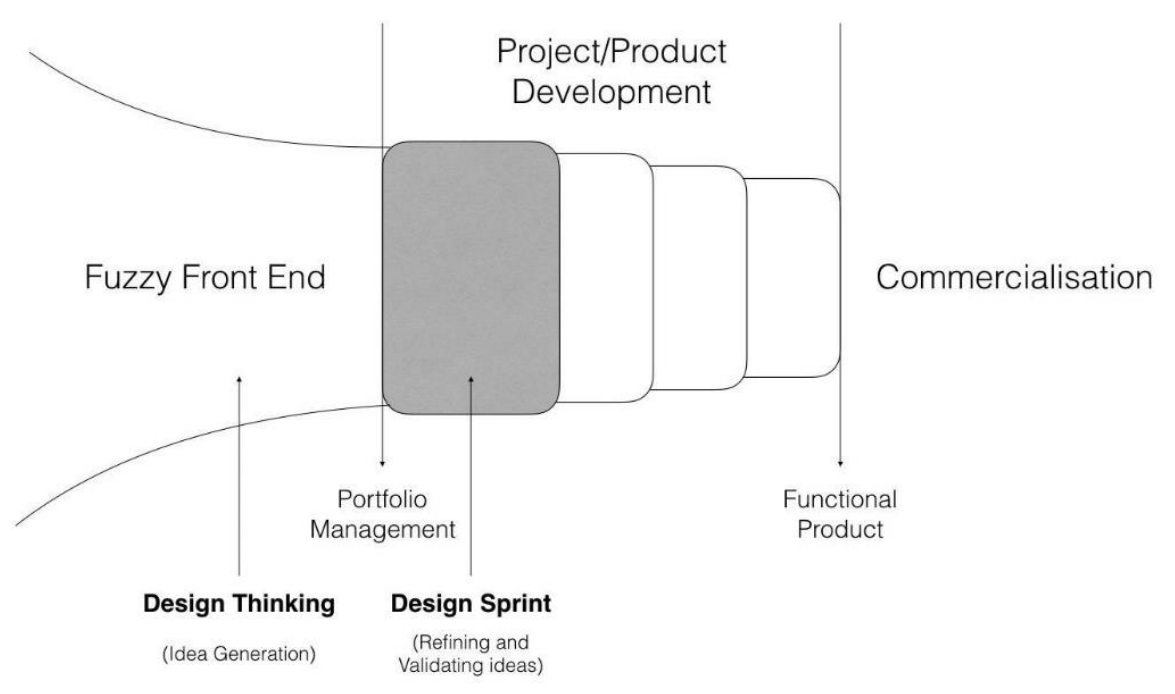

Source: Created by the author, 2018.

In order to corroborate Figure 4, it was evident that in all the DS processes that this is more efficient when there is a well-defined work scope. Because the understanding is made entirely from internal knowledge of the company and experts, without time for external analysis and observations, the participants are limited to working with inputs of what is already known by the other participants. In this sense, to work on the solution of wicked problems, there is an evident need for the participation of experts who contribute great knowledge to the participants of the sprint, or that include a previous stage for the participants to understand unknown external variables, or even the generation of high level ideas, as in DT processes.

\subsection{Limitations of this study and next steps for research}

Although multiple processes were evaluated, they were all oriented to solve problems related to the same digital product, and it might be interesting to evaluate the DS for other digital products or even for products of other natures.

It is also important to note that because some changes were made to the original DS process (i.e.: stakeholders validation instead of end-user validation of the solution, inclusion of an extra phase of technical understanding of the product after the separation of groups) of the 
DS process itself. Another possible future study would be so evaluate the difference between end-user to stakeholder product validation.

Despite the wide use of this methodology in the organizational field and several reports pointing to the benefits of implementing DS (Google Ventures, 2017), the literature does not present an evaluation of which critical success factors and which key performance indicators (KPIs) DS processes positively contribute to the success of the product or project, as done for DT processes in Lopes et al. (2016). Through an adequate relationship, one could understand which techniques are most important for the product and how the processes can be adapted to each context considering the different factors and most relevant indicators in each environment. Another potential field to be studied is to understand how this initial design work of the product can be integrated to its development, as proposed in Figure 4, and eventually how the DS contrasts with the current models of requirements definition (e.g. backlog of user stories for agile development).

\section{CONCLUSION}

With increasingly competitive markets and consumers, organizations are looking for constant innovation at low cost as a way of surviving. In this scenario, DS appears as an ideal methodology for the business community to develop innovative products, services, processes and strategies. By using DT techniques and incorporating the principles of LS, DS enables an organization to reduce uncertainty in the process of creating new products. This research contributes to the literature by exploring a still incipient area in the literature and answering three research questions about what Design Sprint is, its differences from the Design Thinking processes, and why this methodology has soon become one of the references for practitioners in the Brazilian market (TEIXEIRA, 2017). The analysis of DS case studies points to some advantages of this process, as compared to DT processes, which justifies the popularization of this methodology, such as low experimentation barrier, alignment with high management for continuing the work, orientation to incremental innovations and work on defined scope. These differences suggest DS can be even more efficient when used as an initial stage of new product development than as a methodology for generating new ideas. 
Although the limitations of this study consider DS processes adapted and only related to a digital product, this research brings a contribution by conceptually investigating an unpublished theme that is highly widespread in organizations and paves the way to future studies that can investigate the use of DS in diverse contexts of product creation, such as mapping, which are the critical success factors and performance indicators that are benefited to understand how DS increases the success rate of new products or, as proposed by the authors, to understand how the integration of this DS can be made for developing the product itself.

\section{References}

AMORIM, C. C. Um Modelo de Aplicação do Design Thinking para o Gerenciamento de Projetos de Inovação. 2017. Disponível em: https://www.researchgate.net/publication/316735292_Um_Modelo_de_Aplicacao_do_Design _Thinking_para_o_Gerenciamento_de_Projetos_de_Inovacao . Acesso em: 20 mai. 2017.

BECKMAN, S. L.; BARRY, M. Innovation as a learning process: Embedding design thinking. California Management Review, v.50, n. 1, p. 25-56, 2007.

BERGER, W. The Secret Phrase Top Innovators Use. Harvard Business Review. Disponível em: https://hbr.org/2012/09/the-secret-phrase-top-innovato. Acesso em: 12 jun. 2017.

BICEN, P.; JOHNSON, W.H.A. Radical Innovation with Limited Resources in High-Turbulent Markets: The Role of Lean Innovation Capability. Creativity and Innovation Management, v. 24, n. 2, p. 278-299, 2015.

BLANK, S. G. The Four Steps to the Epiphany. Foster City, Calif.: Cafepress.com. 2006.

BLANK, S. Why the Lean Start-Up Changes Everything? Harvard Business Review, 2013. Disponível em: https://hbr.org/2013/05/why-the-lean-start-up-changes-everything. Acesso em: 12 jun. 2017.

BLOCH, P. Product design and marketing: Reflections after fifteen years. Journal of Product Innovation Management, v. 28, p. 378-80, 2011.

BLOMBERG, J.; BURRELL, M. An ethnographic approach to design. The Human-computer interaction handbook, p. 965-988, 2008.

BRESSAN, F. O método do estudo de caso e seu uso em administração. Administração On line, v. 1. n. 1, 2000. 
BROERS, W.; REUVER, M. Applying Agile Design Sprint Methods in Action Design Research: Prototyping a Health and Wellbeing Platform. Tackling Society's Grand Challenges with Design Science, p. 68-80, 2016.

BROWN, T. Design Thinking. Harvard Business Review. 2008. Disponível em: https://hbr.org/2008/06/design-thinking. Acesso em: 12 jun. 2017.

BROWN, T. Change by design. How design thinking can transform organizations and inspire innovation. New York: Harper Collins Publishers, 2009

BUCHANAN, R. Wicked Problems in Design Thinking. Design Issues, v. 8, n. 2, p. 5-21, 1992.

CARLETON, T.; COCKAYNE, W. R.; TAHVANAINEN, A. J. Playbook for Strategic Foresight and Innovation: A Hands-on Guide for Modeling, Designing, and Leading Your Company's Next Radical Innovation. 2013 Disponível em: https://www.thegeniusworks.com/wp-content/uploads/2016/01/Playbook-for-StrategicForesight-and-Innovation-A4.pdf. Acesso em: 12 jun. 2017.

CARVALHO, M. M.; RABECHINI Jr, R. Fundamentos em Gestão de Projetos: Construindo Competências para Gerenciar Projetos. São Paulo: Atlas, 2011

COOPER, R. G. Third-generation new product processes. Journal of Product Innovation Management, v. 11, n.1, p. 3-14, 1994.

COOPER, R. G. The Stage-Gate idea-to-launch process - Update: what's new and next-gen systems. Journal of Product Innovation Management, v.25, n.3, p. 213-232, 2008.

COOPER, R. G. Winning at New Products: Creating Value Through Innovation. New York: Basic Books-Perseus, 2011.

COOPER, R. G. What's Next? After Stage-Gate. Research-Technology Management, v.57, n.1, p. 20-31, 2014.

CROOM, S. Introduction to Research Methodology in OM' in Introduction to Researching Operations Management. New York: Taylor and Wilson, p. 42-83, 2009.

D.SCHOOL: Bootcamp bootleg. Stanford University Institute of Design. Stanford. Disponível em: https://dschool.stanford.edu/resources/the-bootcamp-bootleg. Acesso em: 28 jul. 2016.

DA SILVA, T. S.; SILVEIRA, M. S.; MAURER, F.; SILVEIRA, F. F. The Evolution of Agile UXD. Information and Software Technology, v. 102, p.1-5, 2018.

DOROW, P.; FRANZONI, C.; TORQUATO, M.; FIALHO, F. Ferramentas do design thinking para a inovação em modelo de negócio. Ciências \& Cognição, v.21, n.1, 2016. 
DORST, K. The core of 'design thinking' and its application. Design Studies, v.32, p.521-532, 2011.

EISENHARDT, K. M. Building Theories from Case Study Research. Academy of Management Review, v. 14, n. 4, p. 532-550, 1989.

GEISSDOERFER, M.; BOCKEN N. M. P.; HULTINK, E. J. Design thinking to enhance the sustainable business modelling process - A workshop based on a value mapping process. Journal of Cleaner Production, v. 135, p.1218-1232, 2016.

GOOGLE VENTURES. Design Sprint Methods. Disponível em: https://designsprintkit.withgoogle.com/. Acesso em: 10 out. 2016.

GOOGLE VENTURES. Sprint Stories. Disponível em : https://sprintstories.com/. Acesso em: 12 jul. 2017.

HANGOUTS FOR ENTREPRENEURS: Lean Startup Meets Design Thinking in 10 Minutes. Disponível em :https://www.youtube.com/watch?v=JzEg-Y0noRY. Acesso em: 20 mar. 2019.

HARMS, R. Self-regulated learning, team learning and project performance in entrepreneurship education: Learning in a lean startup environment. Technological Forecasting and Social Change, 2015.Disponível em: https://ideas.repec.org/a/eee/tefoso/v100y2015icp21-28.html. Acesso em: 20 mar. 2019.

IDEO. HCD - Human Centered Design - toolkit. IDEO.ORG, v.2, 2009.

IDEO. Design Thinking for Educators. Evolution, 2011.

IDEO. The Field Guide to human-centered design. IDEO.ORG, 2015.

KNAPP, J.; ZERATSKY, J.; KOWITZ, B. Sprint: How to Solve Big Problems and Test New Ideas in Just Five Days. Simon and Schuster, Google Ventures, 2016

KOEN, P.; AJAMIAN, G.; BURKART, R.; CLAMEN, A.; DAVIDSON, J.; D'AMORE, R.; ELKINS, C.; HERALD, K.; INCORVIA, M.; JOHNSON, A. AND KAROL, R. Providing clarity and a common language to the "fuzzy front end". Research-Technology Management, v.44, n.2, p. 46-55, 2001.

LIEDTKA, J. In defense of strategy as design. California Management Review. v.42, n.3, p. $8-30,2000$

LIEDTKA, J. Perspective: Linking Design Thinking with Innovation Outcomes through Cognitive Bias Reduction. Journal of Product Innovation Management, v. 32, n. 6, p. 925 938, 2015.

GEPROS. Gestão da Produção, Operações e Sistemas, v. 14, nº 5, p. 23 - 47, 2019. 
LOCKWOOD, T. Design Thinking Integrating Innovation, Customer Experience, and Brand Value. New York: Allworth Press, 2009.

LOPES, K. M.; CARVALHO, M. M.; ZANCUL, E. S. Diferentes perspectivas de sucesso em projetos de inovação: uma análise comparativa das abordagens Design for Six Sigma e Design Thinking. GEPROS. Gestão da Produção, Operações e Sistemas, v. 11, n. 3, p. 211-228, 2016.

LUDWIG, D. The era of management is over. Ecosystem, v.4, p.758-764, 2001.

MUELLER, R.; THORING, K. Design thinking vs. Lean startup: a comparison of two userdriven innovation strategies. International Design Management Research Conference, 2012. Disponível

em: https://www.researchgate.net/publication/234066097_DESIGN_THINKING_VS_LEAN_ST ARTUP_A_COMPARISON_OF_TWO_USER-DRIVEN_INNOVATION_STRATEGIES. Acesso em: 20 mar. 2019.

OWEN, C. Design thinking: Notes on its nature and use. Research Quarterly. v.2, n.1, p. 1627, 2007.

PlatTNER, H.; MEINEL, C.; WEINBERG, U. Design Thinking. Munich: miwirtschaftsbuch , 2009.

RIES, E. The lean startup: How today's entrepreneurs use continuous innovation to create radically successful businesses. Crown Books, 2011.

RITTEL, H. On the planning crisis: Systems analysis of the first and second generations. Institute of Urban and Regional Development, v.8, p. 390-96, 1972.

RITTEL, H.; WEBBER, M. Dilemmas in a General Theory of Planning. Policy Sciences, v.4, n.2, p. 155-169, 1973.

ROBERTSON, T. The Process of Innovation and the Diffusion of Innovation. Journal of Marketing, v.31, p.14-19, 1967.

ROWE, P. Design thinking. Cambridge, MA: The MIT Press, 1987.

SCHUMPETER, J. The Creative Response in Economic History. Essays on Entrepreneurs, Innovations, Business Cycles, and the Evolution of Capitalism. 1989.

SHIN, C.; THOMAS, J. Exploring the Emotional Experience of the user and Designer, Both in the Design Process and Classroom. Procedia Manufacturing, v.3, p. 2267-2274, 2015. 
SIMON, H. The structure of ill-structured problem. Artificial Intelligence, v.4, p.1981-201, 1973.

TEIXEIRA, F. Resultados da pesquisa: panorama do mercado de UX no Brasil. Disponível em: https://brasil.uxdesign.cc/panorama-do-mercado-de-ux-no-brasil-2fa1164a1f85. Acesso em: 12 jul. 2017.

THOMAS, J.; SHIN, C. Implementing Design Sprints in the Education of Industrial Designers. Design Principles and Practices: An International Journal, v. 10, p. 59-73, 2016.

VECHAKUL, J. Human-Centered Design as an Approach for Place-Based Innovation in Public Health: A Case Study from Oakland, California. Maternal and Child Health Journal, v. 19, p. 2552-2559, 2015.

VIANNA, M.; VIANNA, Y.; ADLER, I. K.; LUCENA, B.; RUSSO, B. Design Thinking: inovação em negócios. Rio de Janeiro: MJV Press, 2011.

VOSS, C.; TSIKRIKTSIS, N.; FROHLICH, M. Case research in operations management. International Journal of Operations \& Production Management, v. 22, n. 2, p.195-219, 2002.

WOMACK, J. Lean thinking: banish waste and create wealth in your corporation. New York: Free Press, 2013.

WYLANT, B. Design Thinking and the Experience of Innovation. Design Issues, v. 24, n. 2, p. 3-14, 2008. 